\title{
Distinguished Features of Islamic Culture and Its Impacts and Blessings on the World
}

Syed Ayaz Ahmed Shah

"Dr. Zahida Parveen

\section{ABSTRACT:}

Our world has numerous cultures. It represents the nation's way of life and the values they have. It is the typical of every nation to try its best to protect its culture and colure other nations in its own culture. Due to such intentions there is always a war between these nations to ruin the culture of another and to make its culture prominent everywhere, however the world doesn't allow another culture to enter in, by force. It needs that the ruler culture must have high values to admit others to follow it. If we have an analytical study of various cultures, we can find that there were many cultures that tried to dominate the entire world but due to many faults in them, they were not accepted by human being. It was only Islamic culture that was accepted whole heartedly by all. Because it was the first culture that brought prosperity to the people. It gave them recognition and strengthened them. The following research paper consists of introduction of Culture, its history, after that I have focused on Islamic Culture, its prominent features and its impact and blessing on humanity.

Keywords: Islamic Culture, Europe, Nationalism, Civilization, Brotherhood.

Literal and Technical Meaning of Culture

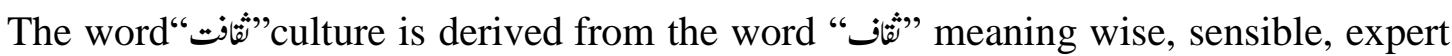
etc ${ }^{1}$. The word “ثأف"is also used for a device to make even and strengthen a spear. Ibne Manzoor-Afriki renders the word“" Lisan ul $\mathrm{Arab}^{2}$. Sometimes this word is also employed for hegemony and victory, as it

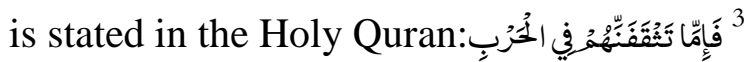

If you ( the Holy Prophet overcome them in battle.

According to experts, culture itself is a type of inherited knowledge which humans acquire to lead their lives. Owing to diversified characteristics, traditions, rituals and habits, every nation is distinguished to others exclusively.

\section{Different Cultures Before the Commencement of the Holy Prophet}

Ahead of the commencement of the Holy Prophet humanity was ignorant of civilized and cultured life. Two of the great superpowers of that time, the Romans and Persians, were thought to be the champions of peace and civilization. Un-fortunately, they were failed to act as responsible states but the representatives of evil and morbidity. Licentious attitude and desires crept among their elite class. On the other

"Ph.D Research Scholar, Department of Quran \& Sunnah, University of Karachi.

Email: ayazcancerian@gmail.com

${ }^{* *}$ Govt: Postgraduate Viqar-un-Nisa College Rawalpindi. 
hand, their middle and lower classes felt proud to copy their masters. Especially, the poor were there to serve their masters' sensuous desires. Whenever tired of this unnatural life, they amused themselves with wine and cheap enjoyment.

Since the religious sentiments were weakened or the prevalent circumstances put it around, in this godless society, humans were falling dawn from the true status of humanity to the pleasures of worldly desires. At that time, the religious leaders and priests had shaped those religions with new modifications and inventions that, if the founders of those religions could survive, surely they would not even recognize them. At that time, only Christianity existed as a religion in the world because a long-ago Jews had been disillusioned with religion and sought after materialistic longings. Similarly, Christianity had no ability to challenge the oppressive system that existed then or form a civilized society. Only a brief glimpse of Jesus' teachings existed there which were also changed over time. St Paul, St Constantine and other religious authorities made Christianity a combination of various myths, lifeless ceremonies and unconventional beliefs. Religious discussions and debates caused questions such as what is the nature of Jesus. How many human and divine attributes did he characterize? These kinds of meaningless and pointless debates were part of everyday discussions.

It is worth mentioning how much those religious sects were hostile to each other and how their behaviour was against their opponents. No one can imagine the enmity among them. The collective life had reached its peak in mismanagement. According to Gabon: "The fall of the empire in the 6th century CE and its plight were endless. It was like a tall, dense tree, under which the nations sought refuge, and then left a dry trunk alone withering day by day. "4

Likewise, Robert Briefault writes:"From the fifth to the tenth century, Europe was in the darkness that was getting darker and fiercer; the brutality of that period was increased like a decaying carcass of culture. The civilized and cultured attitude had wiped out. Countries like Italy and France where fashion and cultured life had brought up and reached to its peak, destruction and desolation were common." ${ }^{5}$

Along with other nations, Jews had a great deal of knowledge, but due to hardships of enslavement and various genocides, they became the victim of hypocritical and mercurial thinking. During the war in Iran and Rome, when the Iranians were initially victorious and Syria was occupied, the Persian King Khosro Prvaiz committed atrocities on Christians only because of the provocation of the Jews. As a result, the Roman emperor, Herakal, did the same and took brutal revenge from the Jews. Only those Jews were able to survivor who had either left the Iranian Empire or hid at someplace.

Iran, who previously held a distinguished place in human history, fell deeply in terms of morality and civilization. Homosexuality and pre- marital relationships, which naturally are hardpressed to establish in civilized societies, were shamele-ssly performed there.

The Iranian nation was subjected to extreme nationalism. Other nations were futile for them. Basically, they were fire-worshippers. Human traits like compassion, patience, 
and gentleness had never existed in them. In terms of ethical conduct, they were no less than behind the other corrupt nations of the world.

At the same time, the situation in India where the great pioneers of civilization, such as the Aryans, Buddhists and Ashokes had passed was not very ideal. Buddhist teachings had also altered; their monotheistic beliefs had disappeared in the practices of idolatry. Their competing attitude against cast system had vanished. Hindu ideology had trod their Buddhist identity and integrated them into the Hindu religion. Dr. Gustauli Ban writes in his book "Civilization in India":

"To understand the essence of Buddhism, it is important to study the monuments and books related to it. They are completely different from the books that European authors have studied. These monuments prove that the European scholars who think Buddhism as monotheistic religion is, in fact, the amalgam of idolatrous and polytheistic beliefs." 6

The caste system had divided Hindu society into different classes. The Aryans employed racial division of human beings into different classes in order to maintain their superiority, because in the same way they could maintain their hierarchy. Regarding this division, Dr Gustauli Ban writes: "At the end of the Vedic period we have seen that different occupations were becoming less widespread and that the division of caste had begun but not completed. The Aryans had realized that they could only protect their racial identity if they keep the defeated nations away from them. By the time they advanced to the East and conquered indigenous nations, this need became even greater and the legislators had to deal with it. They had understood the fact that, if victorious nations who were small in numbers, did not size their offspring mingling with defeated groups, they would soon lose their identity and disappear forever." ${ }^{7}$

Shudder, the lower Hindu caste thought to be considered an inferior creature even than animals in Hindu society. They were forced to live an inhuman life. The holy book, Manu Shastra, maintains highly condemnable laws regarding Shudars. It sounds that these laws are written by an insane person.

Similar to Hindu behaviour, Arabs treated their women badly; they would bury their newborn daughters alive and refuse to give their lawful share of the inheritance. But in India, the life of a woman was even more disastrous. According to Dr Gustav Lee Banu, in Manu Shastra women are considered weak, unfaithful and despised. In his book Civilization in India, he writes: "The holy book Manu Shastra does not mention the ritual of burning the widows with the bodies of their husbands, but it was common in India, as Greek historians have written about it." 8

After her husband's death, she had to either burn with her husband's body or suffer humiliation all her life and become the servant of her deceased husband's family. These women were treated so badly that they choose to be burnt alive with their husband's body instead of leading a humiliating life.

As Indian culture was plunged in abysmal, commencement of Islam, on Indian soil, removed all the darkness. These are some illustrations of renowned civilizations and 
cultures around the world; otherwise, the overall picture was very bleak. However, in the next pages, it will be reviewed in detail how the Islamic culture and its teachings affect the world.

Islam is thought to be a perfect system of life which does not consider any aspect of life separate from religion. After embracing God as our master, Muslims are obliged to obey Him unconditionally. Humans are all the slaves of Allah and they should lead their lives in accordance with the instructions of Allah and the principles and practices of His Messenger, then it will be true worship. Islam brings all aspects of life under its

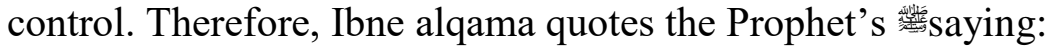

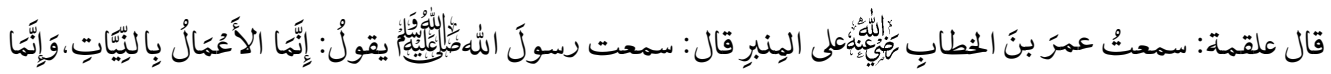

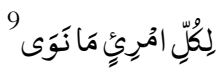

Hazrat Umar says that I have heard from the Prophet intentions, and everyone will receive the same which he intended."

Islam does not leave its believers in confusion, but provides them clear directions which result in a beautiful world and successful future. The Prophet

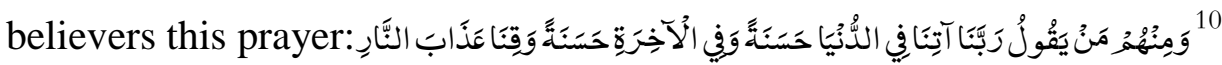

"And there are some of them who say," Our Lord, give us a good life in this world, and in the Hereafter and save us from the punishment of the hellfire."

The following is an introduction to the distinct features of Islamic civilization and its impact on human life:

\section{Belief on Monotheism:}

One of the most effective aspects of Islamic culture is its belief to monotheism. Islam teaches monotheism and frees human beings from the devotion of worldly desires. It makes them aware of the true God and taught humans that all worldly things and phenomena they worship are created to serve humans. All the phenomenal powers like the sun, the moon, the stars, the planets, etc are created by God who created humans. So, recognize and bow your head to Him. Do not damage your honour by worshipping the phenomenal powers of this world. Before the advent of Islam, in India ignorance had reached such an extent that whatever things they perceived as profitable, strong, horrible, or beautiful, they declared that as their deity and started worshipping it. According to the author of

"Ancient India", Dr Ramesh Chandradat:

"Ancient India had a special distinction in the abundance of deities, where idolatry reached its peak in the sixth century $\mathrm{AD}$, and during this period the number of 'gods' reached 33 million." 11

A famous Indian scholar Patekar writes about the impact of Islamic monotheism on India. He says: "It is a proven fact that Islam has had a profound impact on Hinduism; the concept of worship of Allah in Hinduism is the result of Islamic influence. In that period philosophers and religious leaders, though having different names of their gods, also invited their followers to worship Allah and to believe in His oneness that 
deserves to be worshipped, and to whom salvation should be sought. This effect also appeared in the religious reformative movements of the Islamic era, such as Bhagat and Kabir Das movements." 12

Dr. Tara Chandapande, in his book "Socialism in the Mughal Age and the State," also mentions the Islamic influence on the Bhagti movement: "Bhagt was highly respected among the poor and his teachings were followed with great passion; he and his disciples emphasized for human respect because they claimed that everyone could attain the highest level of humanity through his deeds and actions." This movement started in the fifteenth century and continued until the middle of the seventeenth century, but later it gradually died down; although their leading figures belonged to different parts of India, the Islamic influence was evident on their teachings and beliefs." ${ }^{13}$

Therefore, Islam not only reformed the basic faith of man but also greatly influenced other religions. A lot of sensible people, who belonged to different religions, studied Islam and majority of them accepted Islam, but those who decline to acknowledge Islam, at least convinced that Islam is nothing less than a great blessing for humanity. Moreover, the civilization that Islam offers is actually an essence of humanity which offers practical solution from an individual to state functions. Similarly, Islam honors human dignity and self-respect.

\section{Human Brotherhood:}

Just as Islam exerts the concept of monotheism, similarly it encourages the importance of unity among humans, so that the world could become a haven of peace. In fact, many of battles were fought on the basis of nepotism and hatred. History is itself witness this account. So, Islam is a great blessing for the entire humanity. At the different places in the Quran and the Hadith of the Prophet nationalism and nepotism have been rejected because the spirit of nationalism was very high in the Arabs.

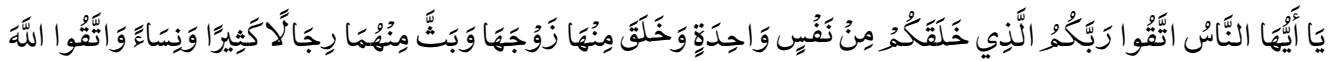

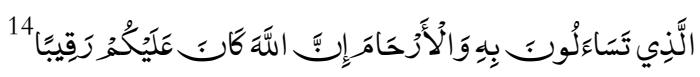

"O, People! Take piety from your Lord, Who created you (all) with one soul, and created from Him a pair, and He spread out of them both men and women: and fear Allah. On whom do you ask one another, and also in the matter of kinship?"

The fear of God and piety are the significant steps towards the establishment of a virtuous and peaceful society, because a person who fears his God will have the qualities that are necessary for the establishment of a virtuous human society. Individuals need these qualities in order to establish a civilized culture. Because of the great emphasis of tribal and ethnic prejudice and pride in the Arabs, the Prophet paid his attention to it particularly. Hazrat Abu Hurayrah narrated to the Prophet

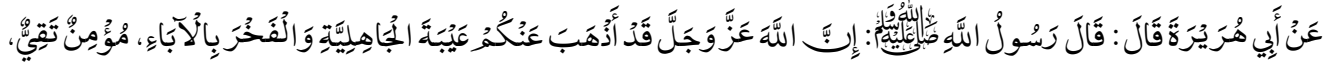

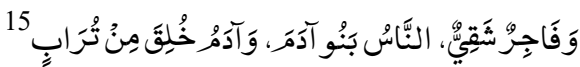

Abu Hurairah says that the Holy Prophet aid:" Allah has removed from you the 
manner of foolishness and pride of your ancestors. People are descendants of Adam and Adam was made of clay.

Just as Islam introduced universal sharia law, so did the model of a universal civilization. Renowned orientalist Professor Gibb explains the importance of Islamic civilization and writes: "Islam has yet to serve another assignment for humanity. ... It is revealed form the diverse societies of Africa, India, Indonesia and Japan that how Islam dissolves different races, traditions, and irreconcilable disputes easily. If mutual co-operation is to be created among the great societies of the East and West, then it is necessary to procure the services of Islam." 16

Likewise, the famous philosopher and historian Tine bay says: "Eradication of racial discrimination among Muslims is one of the great works of Islam, and in the present age, the advent of Islam is the greatest need of the hour ... though the achievements of English-speaking nations have also accomplished some great achievements in the field of science and technology. However, it cannot be denied that the West has been unfortunate in removing racial sentiment." ${ }^{17}$

These two excerpts just provide a small picture; otherwise, the stories of great Muslim civilization are common in the western world. Previously human societies were empty of the idea of human equality which nature demands. So, it can be said that Islamic civilization is consistent with nature.

\section{Human Dignity and Excellence:}

We have read about human history before the commencement of the Prophet previous pages that how the dignitaries of different societies and civilizations disgraced humanity. For the sake of their false gods, they humiliated human beings by preferring lifeless idols and animals on human dignity.

In contrast, Islam unveils the true status of human beings. In fact, they are the vicegerent of God in this world; all of the universe and its objects are created for the benefit and service of mankind. As the Holy Quran says:

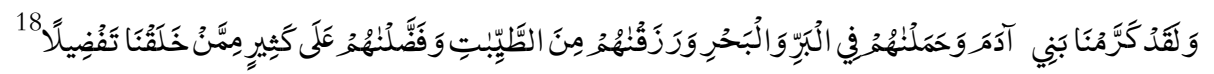

"And We honored the Children of Adam, and We carried them both on dry land and in the river, and We gave them good things and We gave them great excellence over many of our creatures."

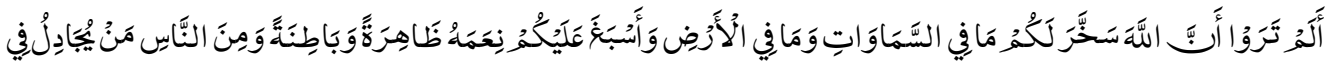

19

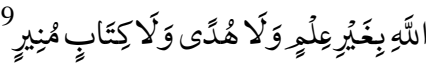

"And do you not see that Allah has subjected to you all that is in the heavens and all that is in the earth, and has fulfilled His blessings upon you in manifest, and in the people without knowledge? They argue in the matter of guidance and the Book of Allah."

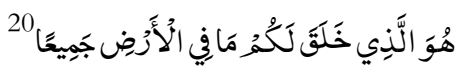

"He is the One who created for you, whatever is in the earth, all of them." 
Similarly, the several Ahadith of the Prophet compassionate towards the people. The Holy Prophet

"The best of people are the ones that benefit other people."

Hazrat Abdullah bin Masood (RA) quotes another tradition of the Holy Prophet:

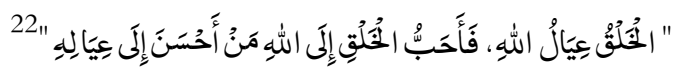

"Abdullah ibn Mas'ud (RA) narrates that the Holy Prophet the family of Allah, and the most beloved of Allah's creatures is the one who does good to his family."

Likewise, Hazrat Abdullah bin Umar narrates from the Prophet :

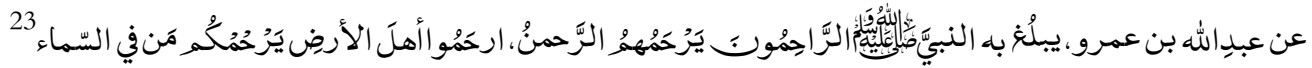

"The Prophet said: The Beneficent Allah is Merciful on those who are merciful, be merciful on the people of earth you will be blessed by those who are in the heaves"

The significance of human life and property in the eyes of Allah and His Prophet evident from the previous verses and Ahadith of the Prophet Allah has declared them as the source of His proximity.

\section{True Status of Women:}

Islam provides the sacred status of mother to a woman. It ensures the personal rights of a woman as a sister, a daughter, and a wife. Firstly, women are endowed with inheritance rights in Islam. If the rights of men are greater as a husband, then women rights are balanced by giving them the higher status of mothers. The man is responsible for taking care of his family financially and women are in charge of nurturing and training the offspring at home. Contrary to Jews and Christians, Islam offers the true status of humanity to women. As the holy Quran describes it:

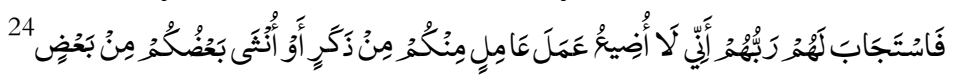

And their Lord answered them, that I will not waste the work of one of you, male or female from one another.

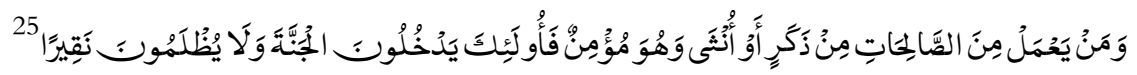

"And whoever does good deeds, whether male or female and has faith, such people will enter Paradise and they will not be wronged."

For the first time in human history, Islam granted the rights of ownership, inheritance, sale, marriage, right to terminate the engagement, right to attend Eid, Friday prayers, etc., as well as the rights which are preserved in the books of Islamic jurisprudence which had never been granted that before. Muslims are well aware that what rights have Islam supplied to women; books of Islamic jurisprudence are full of them, but the unquestionable fact is that even opponents confess this truth of honoring women in Islamic culture.

An Orientalist Mr Colson writes: "Certainly, the Qur'anic laws have a lot of relevance in terms of the status of women, especially in the case of married women. The laws of marriage and divorce are numerous, whose main purpose is to improve the general 
status of women, and this is a sign of a revolutionary change in the laws of the Arabs. Women are provided with the legal status which they lacked previously. The biggest change is made in the laws of annulment of marriage by adding iddat laws ( during that period a woman is not allowed to marry) in them.",26

Likewise, the Encyclopedia of Religion and Ethics mentions the benevolence that Islam bestows to women and provides them with a dignified status: "The Prophet certainly raised the status of women more than what they had achieved in ancient Arab, especially a woman was no longer the beast of her husband's inherited property, but she herself entitled to get hold of her lawful share in patrimony. She was an independent person; nobody could force her to remarry. During the period of Iddat, her former husband was obliged to return all her belongings she had received in marriage. At the same time; although, upper-class women were interested in education and poetry, the women belonged to the middle class began to share her husband's personal and business affairs. Muslim mothers were given the highest status in the family." 27

Many non-Muslim historians and researchers have accepted that elimination of "ritual of satti " became possible in India only because of Islamic teachings. Prior to the Muslims' arrival in India, women were considered to be a lifeless toy which was thrown aside by her husband after receiving sexual satisfaction. Dr. Bernier who came to Mughal emperor Shah Jahan writes: "Nowadays, the number of satti atrocities has diminished because the Muslim rulers of this country try to eliminate this barbaric ritual. No law exists for its prohibition, because Hindus are in majority and according to state policy, it is inappropriate to interfere in their religious life. They are free to practice their religious rituals but the practice of satti is prevented by certain measures as a woman cannot be burnt without the permission of provincial authorities." ${ }^{28}$

Nowadays, different people are working on women's rights; often NGOs are very active regarding this issue. They accuse Islam of not giving women their rights; however, the facts are distorted, because the accusers want to make women naked showcase for men. In fact, Islam has not only rejected this controversy but also celebrated the importance and honour of women.

\section{The Development of Human Psychology and Solution to Misery and Despair:}

A man is a combination of different emotion and psychology. Emotions such as fear, greed, low self-esteem, cowardice, bravery, fearlessness, etc. are part of him. The characteristic of Islamic culture and civilization is that a man not only attributes externally superior qualities, but it emphasizes the inner human traits. In fact, the inner self motivates for external qualities. According to Islamic tradition, the door of forgiveness is open till the death. Islam encourages its adherers to forgive each other's faults because to err is human. So if one feels guilty because of his sin, he should seek absolution from God and feel sorry for himself. Islamic system of life and civilization is free of excess and paucity. It advocates a moderate lifestyle and harmonizes perfectly with human nature. Goodness and righteousness are essential qualities of human nature, while sin and oppression are external and temporary things; they are 
something from outside, not an integral part of human nature.

The door of repentance does not close at any time until death, which is why Islam has given repentance a status of worship in view of the importance and virtue of

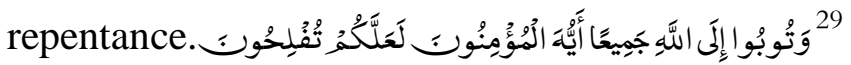

"O you who believe! Repent of Allah with all your heart and hope to be successful!" How kindly and loving way the articles of forgiveness and repentance are described in the Quran, it shows how much God loves His repentant and servant. At different places, adorable style of the Quran draws the human heart toward repentance and God's love. Allah says:

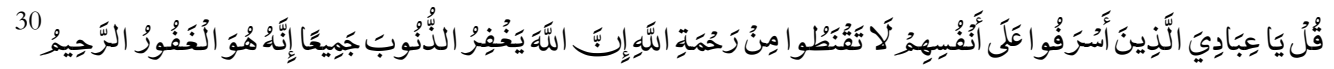

"Say (to me), O, my slave! Whoever has wronged himself, do not despair of the mercy of Allah; surely He is the Forgiving, the Most Merciful."

In addition, the significance of repentance is highlighted differently in hadith and it is explained that there is no need to be despair and dejected because your Lord is Most Merciful and Forgiving. At the same time, Islam forbids people to look down upon or make taboo sense of humor to a repentant person. Moreover, Islam condemns such people who remind a repentant of his/her sinful past, rather in many hadiths, offenders are invited and encouraged to seek repentance because in view of God's happiness, refinement of the inner self and religious practices are the utmost requirement of Islamic doctrine.

Earlier, the Jewish denomination's method of repentance was that their religious leaders had the power to forgive and the repented person had to approach them. However, Islam opens its doors of blessing and glad tidings for human beings. It guides them how to ask forgiveness of your Lord without disclosing of their faults or sins. Your Lord will forgive you and keep your secret. To erect a tower of light in the darkness and to light a candle of hope in times of despair and hopelessness, Islamic culture is a great blessing on the human world.

\section{Rejection of Contradicting Views Related to the Unification of Religion and World:}

Establishment of an Islamic government is an essential part of Islamic doctrine, because the divine Islamic laws and punishments can only be accomplished when the Islamic rule is established; additionally, Islam strongly emphasizes on public welfare. However, the duty of command and prohibition can be fulfilled in the face of government and power; an individual cannot perform this duty entirely. Primarily, an Islamic government establishes law and order, provides best services to its people and secures public basic rights. Islam covers all aspects of family, social, political, economic, individual and collective life, as they all are interconnected. Therefore, the

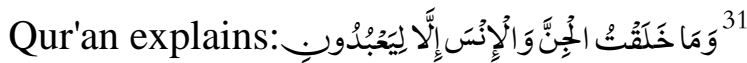

"And I created human beings and jinn just for my worship."

Therefore, under the Islamic system, the whole life of an individual transforms into 
adoration and the whole world becomes a place of worship. Such a sophisticated and humanitarian system is possible owing to Islamic culture and the administrative power helps in the evolution of Islamic culture which is the sign of true humanity.

\section{Establishment of a Sacred Relationship between Religion and Knowledge:}

In the Islamic tradition, the importance of knowledge is evident from the first revelation to the Prophet. The Prophet's own practical life reveals his love for knowledge. But it is honour that he transformed knowledge in religious colour and laid a solid foundation in this regard. So knowledge and religion became the same thing for his companions and believers. As long as the Muslims were the source of knowledge, it continued to be used for the benefit and welfare of mankind, but as the Muslims left behind the West took control of it. They excluded knowledge from religious influence and used it to crush the power of the church. It opened the gates for their own benefits and all the efforts were directed to eradicate God's name from this field. Consequently, such ideas were born which completely rejected God. Now the human were free to fulfil their desires. As a result, horror and destruction swept the world. Two great World Wars erupted in which millions of people were killed. However, Islam enlightens knowledge in its dominance.

Opposite to other religions, Islam developed knowledge on a religious basis. It encouraged people so much of seeking knowledge that many of the people spend their entire lives in the pursuit and dissemination of knowledge. However, some other wellknown religions like Hinduism, Christianity etc. were baffled for the acquisition of knowledge. Here are some examples from the Holy Qur'an to inspire knowledge:قُلْ هَلْ

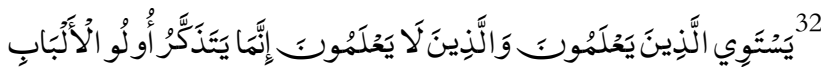

"You ( say whether the knowledgeable and the ignorant can be equal anywhere."

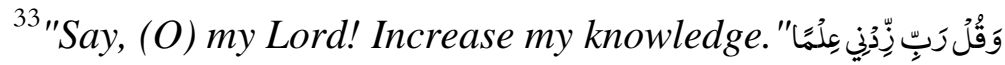

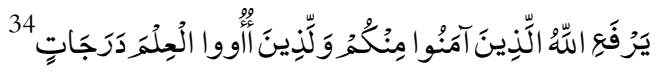

"Allah will raise the levels for those of you who believe and those who have knowledge."

Similarly, Abu Imamah narrates a saying:

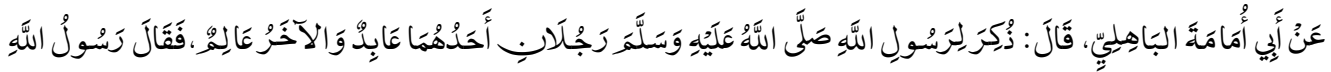

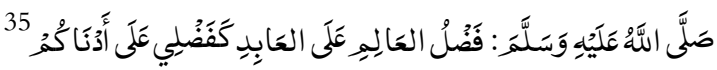

Hazrat Abu Imam says that two men were mentioned in front of the Holy Prophet. One of them was Abid and the other scholar. The Prophet scholar is like that of Abid." The virtue is on the lower man among you. "

Similarly, Abu al-'rda 'narrates another a tradition:

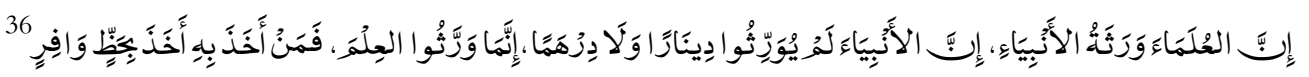

The scholars are the heirs of the Prophets, and the Prophets have not left Dinar Waddham, but this knowledge is left in the inheritance, so whoever got it, got a big share. 
Non-Muslim authors also testify that Islam encourages seeking knowledge. Dr Lebanon, a famous French author, mentions in his work "Civilization of Arab" the knowledge friendliness of Muslims: "The pursuit that the Arabs have shown for knowledge is, in fact, quite unique to many nations, hardly could any other nation take the cake from them. When they captured a city, firstly, they build mosques and madrassas there. These were frequent in the major cities. Benjamin Dali Towel, who died in 1173, states that besides general seminaries he saw twenty great madrassas in Alexandria.Cities like Baghdad, Cairo. Talitalah, Cordoba, etc., had major seminaries where students were involved in academic research for scientific purposes. Liberaries were common; there were seventeen general libraries in Andalusia alone. According to the Arab historians, one of Cordoba's libraries, al-Hakim al-Thani, contained six million volumes, of which forty volumes contained only a list of books.

Contrary to it, four hundred years later when Charles Akil built the Royal Library of France, he could not collect more than a hundred volumes, and neither of these books had a complete cabinet of religious books." ${ }^{37}$

Similarly, in his book Al-Islam-ul-Hazar al-Arabiya, quoting the ideas of Jolivet Castelot, a prominent French intellectual, Mohammed Kurd writes: "After the death of the Prophet the Arabs made rapid progress. It was a favourable time for the dissemination of Islam. At the same time in the process of conquest, Islamic civilization made remarkable progress and promoted everywhere. Soon its influence in theology and philosophy began to rise, and the Arabs continued to hold the flag of intellect in their hands for the next some centuries. Astonishingly, they represented all the scientific knowledge which was concerned with philosophy, astronomy, chemistry, medicine and spiritual sciences. Thus, they were not just intellectual and inventor in literal sense but they accomplished their goals with great skills. Yes, they were rightfully entitled to it. Although the age of Arab civilization was short, but its effects were far-reaching, and we can only regret on its fall. ${ }^{38}$

In short, Islam has shown great potential for the promotion of knowledge in Islamic society which is matchless.

\section{Comprehensive Guidance and Monitoring of Individual Social Life:}

Any doctrine, philosophy and civilization remains alive until a group of its adherers exists and their passion remains firm in their hearts. In fact, no belief system can survive without such ardent followers. In the history, the Prophets have raised their own adherers by offering them moral teachings, but either their nation disobeyed them or their descendants no longer existed. Consequently, their teachings were lost in the blurring of history.

To keep its teachings alive till the last, the Qur'an emphasizes that a group of people should always be prepared to disseminate Quranic teachings. Allah says:

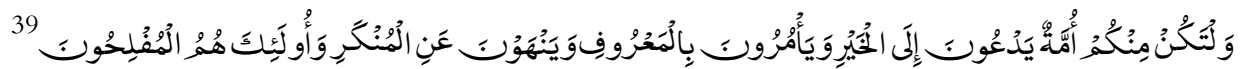

"And surely a group of you should be like that, invite to goodness, order goodness and prevent evil and these are the ones who will prosper." 


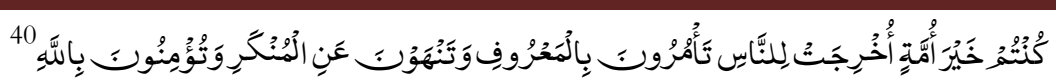

"You are the best of the people, created for the people, you command goodness, and you prevent evil, and you believe in Allah."

Consequently, each of the Companions not only fully realized this responsibility, but also devoted his life to fulfil this endeavour. One of the important aspects of the Islamic revolution is that it emphasized a genuine and true revolution. Therefore, Sayyidina Rabbi ibn Amir made this great speech when he was sent to the court of the Iranian army chief, Rustam. He put the purpose of Islam before him:

الله بعثنا لنخرج من شاء من عبادة العباد الى عبادة الله وحدهومن ضيق الدنيا المى ستها، ومن جور الاديالـ النى عدل

الاسلامر 41

"Allah has sent us to remove anyone whom He wills from the bondage of His servants to the worship of God, and to save the world from its hardships and its cruelty and the oppression of religions. Bring in."

German author Kaitani expresses his views in these words: "Those people were the true representatives of the Prophet's moral heritage, preachers of Islam in the future, and rightful trustees of Muhammad's teachings which he had given to the devotees of God. Constant affinity and love of Prophet had transcended them to a high and affluent world of affairs which no one had perceived before. In fact, a great deal of change had occurred in these people, and later they testified to it during the most difficult times in the battlefield. Those events proved that what Muhammad sown, it cultivated the best individuals with supreme abilities. They were the guardians of the Holy Scripture and protector of each word which they heard from the Prophet These were the respected forerunners of Islam who gave birth to the first scholars and narrators of the Muslim society." 42

Good deeds dominate when they have the opportunity to flourish at the level of society. These occasions come when different societies treat each other according to the teachings of the Prophet at the social, political, financial, and trade level. An exemplary and practical group of the Companions was formed in the light of Prophet's wisdom.

Islam constant observes its adherers so this globally influential movement would not diminish. Through its effect, Islam seeks to make the world a source of peace and prosperity. It emphasizes the call to worship, invocation, discipline through the means of knowledge and education. Consequently, humanity is burdened under the Islamic culture and civilization.

\section{The Universality of Islamic Belief and Civilization:}

How did Islam create unity among Muslims around the world? The answer is Muslims became a nation based on faith and ideology. Living in different regions of the world, there was a linguistic disagreement between them, there were differences in specific living standards, customs, cultures, dresses, etc. of different regions, but Islam accepted them all with legitimate and proper habits of their region. Where it needed 
appropriate modifications were introduced which created a unity among them.

Personal names like Muhammad, Ahmed, Umar, Ali, Usman, Abdul Rahman, Abdullah, Abu Bakar etc are often found in the names of Muslims living in any part of the world. Often when a non-Muslim witness the shahadah and converts to Islam, first he changes his surname to become the part of this universal unity. During the month of Ramadan, Muslims from all over the world observe the fast. Besides fasting rituals, Eid prayers and payment of alms due, there is a universal gathering in Makkah, in which Muslims all over the world revolve around the same house, the Kaba, in the same garments. It expresses the unity of one culture and one nation.

Hamilton Gibb conveys his views in these words: "Islam is a concept, which has appeared in the form of a cohesive but diverse political, social and religious gathering, and has expressed different characteristics in different regions and periods, affecting local, geographical, social and political forces. For example, North-West Africa and the Mediterranean Spain had a deep connection to Muslims living in Western Asia; their civilization was a branch of the same culture, but they produced many distinguishing features that had also influenced Western Asia. From major and selfsufficient regions such as the continent of India, Indonesia, and southern Russia to the borders of China parallel factors produced distinctive features, but all of them maintained their identifiable colours easily." ${ }^{43}$

What influence did Islam have on the civilization of the world? Obviously, it redirected human morality and spirituality in the right direction and created an astonishing unity. The renowned Wilfred Cantwell Smith writes: "The success of the Muslims is the internal success of their religion; they were not just winners in the battlefield, and not only did they affect different walks of life, but in a relatively short period of time they succeeded in making life a more holistic form which is called civilization. In the formation of Islamic civilization, various cultures such as Arab, Greek, the Eastern Mediterranean civilization, Sassanid Iranian, and Indian participated. As a result, they shared all these elements together and transformed into a unified force. Certainly, Islam fulfilled the dream of unity and kept them together. It provided guidance in every aspect of life, regardless of the nature of its syntactic elements. As Islamic Sharia law is central in unifying different cultures, the Islamic way of life strengthens society. Islam through its powerful and determined stream of affairs regulated everything from rituals to ownership. Sharia law gave unity to the Islamic society from Cordoba to Multan. It gave all the activities of human life a meaningful divine colour. Islamic doctrine does not dependent on personalities, different rulers came and left, but their status was limited to mere subservient in accordance with the Lord's commandments." 44

The most obvious and significant thing in the culture and life of a Muslim is the remembrance of Allah and deep concentration at all times.

However, there may be some differences in style of dress and behaviour locally depending on the nature and pattern of the different regions or the climatic variations. 
One thing that paints them all in a single colour is the colour of Allah, which converts them all in one entity.

\section{Conclusion and Recommendation:}

Culture is an inherent knowledge which future generations use to lead their lives. Before the commencement of the Holy Prophet the great civilizations like Persian or Roman had ruined their cultural norms and good manners. Especially in the Arabian Peninsula, women were treated insanely; girls were buried alive because their birth was thought to be a disgraceful event. There was no such thing as equality between man and woman. With the blessings of the Prophet, humanity experienced a new culture and civilization. Islam provided guidance for every aspect of human life, whether it is individual or collective life. It established a system of brotherhood and created love among human beings which was a novel idea for human society in the past. The true status of a human being in this world revealed; especially, the dignity of women was restored through Islamic teachings. Conclusively, Islam laid its foundations of culture and civilization on such principles that are parallel with human nature.

Although our culture is unique, we are blindly adopting foreign colure. If we protect our culture and youth, we will be secured from misguidance.

To achieve this goal, we should refer to the Quran and the Sunnah.

A course on Islamic culture and civilization should be incorporated as a compulsory subject in all our religious seminaries and public educational institutions.

To disseminate Islamic culture, Islamic scholars will have to write and speak persistently.

Similarly, the government will have to take measures to publicize Islamic culture and civilization on the media, because usually, people give more time to media than reading books. Special talk shows and discussions should be aired to attract people's interest.

\section{References:}

${ }^{1}$ Iamail , Abu Nazar. Assihah, Beirut, Darulkutub al Arabia.1999.vol,4. p:28

${ }^{2} \mathrm{Al}$ Afriqui, Ibn e Manzoor. Lisan ul Arab. Egypt, Dar ul hadith Alqahira. 2003. p:684

${ }^{3} \mathrm{Al}$ anfal.8:57

${ }^{4}$ Gibbon, Edward. The Decline and Fall of the Roman Empire. Delmarva Publications. 2015. vol, $5, \mathrm{p}: 31$

${ }^{5}$ Allen, George, V \& Unwin. The making of humanity, W.C London, limited Ruskin House 40, Museum Street. p:164

${ }^{6}$ Dr Gustau, Li ban. Tamaddun e hind, Translated by Syed Ali Bilgarami. Lahore, Maqbol Academy, 1961. p:365.

${ }^{7}$ Ibid: p:311.

${ }^{8}$ Ibid: p:236-238.

${ }^{9}$ Bukhari, Mohammd bin Ismail. Saheh al Bukhari .Dar e Tuqu ul Najat .p:6 verse:1

${ }^{10} \mathrm{Al}$ baqara. 2:201

${ }^{11}$ Dutt, R.C. Acient India. Delhi,1st Edition 1891. Vol:3, p:276

${ }^{12}$ Panikkar, K. M. A Survey of Indian History, Culcutta .Edition 1986. p:132 
${ }^{13}$ Chand, Dr Tara. Society \& The State in The Mughal Period. Delhi, 1941. p:91

${ }^{14} \mathrm{Al}$ maaidah.4:1

${ }^{15}$ Behaqi, Abu baker. Al adab o lil behaqi. Beirut, Maktaba Muassasa al Saqafa. 1988. p:139, verse: 338

${ }^{16}$ Gibb, H.A. R. Whither Islam, London, 1932. p:379

${ }^{17}$ Toynbee, A.J. Civilization on Trial, New York, 1948. p: 205

${ }^{18} \mathrm{Al}$ asra, $17: 7$

${ }^{19}$ Luqman 31:20

${ }^{20} \mathrm{Al}$ baqarah, 2:29

${ }^{21} \mathrm{Al}$ Sarakhsi, Muhammad bin Ahmad. Al Mubsoot, Beirut, Dar ul Marifa. vol:4, p: 194 .

${ }^{22} \mathrm{Al}$ Behaq, Abu baker. Shuab ul Eman. Riyadh, Maktaba ur Rushd, 2003. vol:9, p: 523, verse: 7048

${ }^{23}$ Sulaiman, Abu Dawood. Sunan e Abu Dawood, Beirut Al Maktabat ul Asriya 2003. vol: 4, p:285, verse: 24. Al Qur'an: 3/195.

${ }^{24} \mathrm{Al}$ maaidah 5:124

${ }^{25}$ An nisa 4:123

${ }^{26}$ Coulsen, N.L. A history of Islamic law. Edinburg, 1971.p: 14

${ }^{27}$ Encyclopedia of religion and Ethics, New York. 1912. p: 271

${ }^{28}$ Doctor Bernier. Safernama Amritsar, India, 1886. p: 172-174

${ }^{29}$ An 4 ur 24/:31

${ }^{30}$ Az zumar: 39:53

${ }^{31}$ Ad dhariya. 51:56

${ }^{32} \mathrm{Az}$ zumar. 39:9

${ }^{33}$ Ta ha. 20:114

${ }^{34} \mathrm{Al}$ mujadilah. 58:11

${ }^{35} \mathrm{Al}$ termizi. Sunan e Termizi, Egypt, Maktaba Misatafa Al Babi Al Halabi 1975.

${ }^{36}$ Ibid. p: 48 , verse: 2682

${ }^{37} \mathrm{Dr}$ Gustau, Li ban. Tamaddun e hind, Translated by Syed Ali Bilgarami. p:398-399.

${ }^{38}$ Ali, Kurd Muhammad. Al Islam o walhdhara al Arabia, Uter Perdesh, Dar ul Musannifin , 1986, vol:2, p: 543.

${ }^{39} \mathrm{Al}$ imran. 3:104

${ }^{40} \mathrm{Al}$ imran. 3:110

${ }^{41}$ Ibn-e-Kaseer. Al Bidaya wl Nihaya. Beirut, Dar ihya Alturas lilArabi, 1987, vol.7, p:39.

${ }^{42}$ Caetani Annalidel Islam Vol.II p:429, With reference to Arnold T.W. Preaching of Islam, London, 1925. p: 41-42.

${ }^{43}$ Hamilton. A. R. Gibb. Studies on the civilization of Islam, London, 1962. p: 3

${ }^{44}$ Smith, Wilfred Cantwell. Islam in Modern History, New York, 1957. p: 36

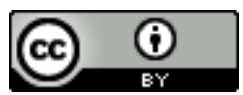

This work is licensed under a Creative Commons Attribution 4.0 International License. 